\title{
Hedonic and Utilitarian Shopper Types in Evolved and CReated Retall AGgLOMERATIONS
}

Christoph Teller • Thomas Reutterer • Peter Schnedlitz

Institute for Retailing and Marketing, Vienna University of Economics and Business Administration, Augasse 2-6, A-1090 Vienna, Austria

Email: \{christoph.teller@wu-wien.ac.at, thomas.reutterer@wu-wien.ac.at, peter.schnedlitz@wu-wien.ac.at\}

$$
\begin{aligned}
& \text { TEL: }++43-1-31336-4622 \\
& \text { FAX: }++43-1-31336-717
\end{aligned}
$$

Accepted for publication in

The International Review of Retail, Distribution and Consumer Research 2008, Volume 18 


\title{
Hedonic ANd Utilitarian Shopper Types in Evolved ANd CReated RetaIL \\ AGgLOMERATIONS
}

\begin{abstract}
This paper focuses on the impact of hedonic and utilitarian values of shopping on retail agglomeration patronage issues, in particular on shopping behaviour and the perception of retail agglomerations. Our empirical study is based on a discussion of agglomerations' potential to attract utilitarian and hedonic shopper types. A sample of 2,139 customers were interviewed in a peripheral shopping mall as well as on an inner city shopping street and confronted with a multi-item scale operationalising shopping values as developed by Babin et al. (1994). Using a standard fuzzy c-means clustering algorithm we identified four distinct shopper types. The results show that hedonists are represented by a higher number of females, earn lower individual incomes and are less educated compared to utilitarians. Interestingly, a higher share of hedonists visited the shopping mall. Overall, they make more shopping trips to agglomerations, stay there longer, visit more stores and - depending on the agglomeration format - spend less than or the same amount as utilitarians. Finally, we see that those customers who are attracted by agglomerations because of atmospheric and price stimuli are typical hedonists.
\end{abstract}

Keywords: retail agglomeration, retail patronage, hedonic and utilitarian shopping orientation, shopping behaviour 


\section{INTRODUCTION}

Consumers visit stores and, for a variety of reasons, undertake shopping endeavours such as planning, transportation, picking or packing (Ingene, 1984; Granzin and Bahn, 1989). This does not only happen for purchasing or procuring products or services that satisfy emerging wants and needs but also to seek other values of shopping such as recreation, socialisation, information, self gratification, etc. (Sheth et al., 1999). Babin et al. (1994) or Jones et al. (2006) call these reasons and motives 'shopping values' and distinguish between two types. Firstly, they identify the utilitarian values of shopping, meaning that consumers look out for and concentrate on the most generic goal of shopping, i.e. to get the right product for the right price and at a minimum effort or cost. Secondly, they identify hedonic values which represent entertainment and emotional worth. Based on these distinctions it is proposed to carry out a psychographic taxonomy of consumers who show a preference for one of the two values, i.e. utilitarian and hedonic shoppers (Babin et al., 1994).

From a retail point of view, this perspective of customer values and preferences can become of crucial relevance as it contributes to answering the question of 'why people shop', closely connected to the answer of 'where people shop' or which shopping destinations are patronised by consumers (Sheth et al., 1991; Woodside and Trappey, 1992). Depending on the applied marketing mix (shopping) hedonists and utilitarians prefer store formats to different degrees (Westbrook and Black, 1985; Rintamäki et al., 2007). For instance, the choice of store location and the provision of parking facilities attract more utilitarians whereas the use of atmospheric stimuli such as music, aroma or light may appeal more to hedonists.

This issue is even more relevant when undertaking a supra-store perspective and in considering retail agglomerations (Babin et al., 1994; Kang and Kim, 1999; Kim, 2002). Retail agglomerations like shopping malls and shopping streets are increasingly being called shopping destinations since they provide multi-purpose shopping opportunities which are 
enriched through other leisure opportunities, e.g. going to cinemas, food courts, etc.. As a consequence, they are perceived to be attractive or preferable for hedonic and/or utilitarian consumers who show a different shopping trip and buying behaviour (Kang and Kim, 1999). This may include general patronage intentions, agglomeration choice, retention time, shopping basket size, number of stores visited per trip, etc. (Jones et al., 2006).

Although Westbrook and Black (1985) indicated the high relevance of such a distinctive view of shopping values sought by respective customer groups for retail management in the mid 1980s, studies and literature to date have neglected this phenomenon on an agglomeration level. In fact, competition between agglomeration formats has increased in the last decade. In particular, a shift of market share from evolved (i.e. shopping streets or retail clusters in town centres) to created agglomerations (i.e. shopping centres or malls) can be regarded as an important trend in retailing (ICSC, 2005; ICSC, 2002; Wakefield and Baker, 1998; Alzubaidi et al., 1997; Marjanen, 1995). A limited number of publications have dealt with patronage issues in relation to hedonic and utilitarian shoppers in retail agglomerations. A distinctive view, however, towards different kinds of agglomerations (termed agglomeration formats), such as evolved and created ones, is completely missing.

Taking into account these shortcomings and the crucial practical importance of understanding the determinants of retail agglomeration patronage (Reynolds et al., 2002) we drew up the following research question: How do utilitarian compared to hedonic shopper types differ with respect to their shopping behaviour in and their perceptions of retail agglomerations?

One goal, therefore, of this paper is to derive a taxonomy that reflects the different notions of shopping values. Another objective is to identify the basic differences across these previously defined groups towards selected agglomeration patronage issues. 
The structure of this paper is as follows: Following a brief justification of the research phenomenon we describe hedonic and utilitarian shopper types in general and the potential attraction of particular agglomeration characteristics for these customer types. Based on that, the conceptual framework is described and four hypotheses are provided. They are tested based on an empirical study which will be introduced in the following section. The presentation of the empirical results include the identification of hedonic and utilitarian shopper types based on a cluster analysis and, consequently, the comparison of the diverse types with regard to their demographic and socio-economic variables, their shopping behaviour and their agglomeration patronage. In addition to that, type-specific perceptions of agglomerations' characteristics based on the results of discriminant analyses are identified. The core-findings and the limitations of our study are summarised in the concluding section.

\section{HEDONIC AND UTILITARIAN VALUE OF SHOPPING IN RETAIL AGGLOMERATIONS}

\section{Hedonic and Utilitarian Shopper Types}

Several authors have focused in the past on shopping values and the underlying psychographic orientation of consumers. Most of them have discussed and/or empirically evaluated this phenomenon with respect to buying behaviour when shopping for particular products in single stores but only a few have enlarged on its impact with regard to shopping in agglomerations (Arnold and Reynolds, 2003). Extensive literature reviews can be found with e.g. Rintamäki et al. (2006/2007), Arnold and Reynolds (2003), Babin et. al. (1994) or Hirschman and Holbrook (1982).

Publications dealing with values concerning shopping in retail agglomerations stress issues such as the impact of perceived shopping values on agglomeration image, shopping behaviour and experience (e.g. Langrehr, 1991; Haytko and Baker, 2004; Kim, 2002), the moderating effect on reactions towards the situational aspects of shopping (e.g. Zhuang et al., 2006) or cross-cultural comparisons of shopper characteristics (e.g. Jin and Sternquist, 
2004). Nevertheless, none of the publications differentiate between distinct agglomeration formats in general and include evolved agglomerations in particular. In fact, Kim (2006) explicitly investigates shopper types relative to inner and outer city customers. By doing so, different types of hedonists and utilitarians are identified from the seminal work of Arnold and Reynolds (2003) and Babin et al. (1994). These shopper types are compared according to their demographic characterisation and their attitude towards retailers. Although Kim's (2006) results only account for a typical American urban retail environment and while the external validity, due to the high non-response problem, is rather limited, her paper provides an appropriate approach on which we can build.

In general, the hedonic value of shopping represents the benefit a consumer gets from the shopping process and not necessarily from the transaction and capability of the product to satisfy wants and needs itself (Jones et al., 2006; Babin et. al., 1994). In contrast, the utilitarian shopping value can be obtained from the efficiency of the shopping process (Jones et al., 2006; Kim, 2002). Efficiency can be understood as the optimal ratio between the output, i.e. purchase the right product or service at the right price, and input, i.e. shopping efforts or use of resources (e.g. time, means of transport) (Ingene, 1984; Granzin et al., 1997).

As an outcome of the preference for one of the two values we distinguish between two stereotypes: the (shopping) hedonist and the (shopping) utilitarian (e.g. Jones et al., 2006; Babin et al., 1994). Hedonic shoppers are intrinsically motivated towards shopping and looking for fun, amusement, fantasy and sensory stimulation. Utilitarians are extrinsically motivated and more task-related and rational (Babin et al., 1994; Batra and Ahtola, 1991). They look for a shopping experience and the convenience that makes their lives more enjoyable and easier (Kim, 2002). Arnold and Reynolds (2003) and Babin et al. (1994) provide different measurement approaches and operationalise these particular shopper types by developing multi-item scales. 
Since several authors have already enlarged on the topic we only summarise the specification of these two shopper types as depicted in Table 1:

Table 1: Characterisation of shopping hedonists and utilitarians (Rintamäki et al., 2006)

\begin{tabular}{|c|c|c|}
\hline Characterisation & Utilitarian & Hedonist \\
\hline Perspective/view & $\begin{array}{l}\text { Cognitive } \\
\text { Information-processing }\end{array}$ & Experiential \\
\hline Purpose of consumption & Means to some predefined end & An end in itself \\
\hline Criterion benefits & $\begin{array}{l}\text { Economical } \\
\text { Monetary savings, convenience }\end{array}$ & $\begin{array}{l}\text { Emotional entertainment, } \\
\text { exploration }\end{array}$ \\
\hline Sacrifices & Money, time and effort & Stress, negative emotions \\
\hline Synonym & Homo economicus & Homo ludens \\
\hline
\end{tabular}

As a result of this literature review, we conclude that authors have identified the existence of homogenous customer groups with respect to their utilitarian and hedonic shopping orientation. Furthermore, these groups are supposed to differ according to their perception of store (agglomeration) characteristics and show a different shopping behaviour. ${ }^{1}$

As a result, this phenomenon becomes of practical relevance for retailers and agglomeration managers (Westbrook and Black, 1985). Applied retail marketing strategies and actions can influence the shopping experience and store/agglomeration patronage, image and buying behaviour on site (Langrehr, 1991; Haytko and Baker, 2004). Therefore, the knowledge acquired about the hedonic and utilitarian orientation of its customers can help retailers to rethink their marketing strategy and change it to the demand of their identified customer groups belonging to different shopper types (Rintamäki et al., 2007; Westbrook and Black, 1985).

${ }^{1}$ Such a stereotypical view implies a person's general orientation towards shopping. Of course, this may be moderated by situational aspects such as the shopping task, product category, shopping situation, etc., which is not of further relevance in the present context. 


\section{Agglomeration Effects and Shopping Values}

Compared to single stores, retail agglomerations augment the shopping experience for their customers in many different ways. This can be regarded as agglomeration effects or synergies (Gosh, 1986). Since these effects can contribute to the hedonic and utilitarian value of shopping we will present the most important ones that are beneficial for customers (Kim, 2002). Based on an extensive literature review dealing with store or agglomeration patronage we suggest the following typology of agglomeration effects (see Table 2).

\section{Rationalisation-Effect}

When shopping in (sets of) store-based retail formats customers have to fulfil numerous logistics tasks (Ingene, 1984; Granzin and Bahn, 1989; Granzin et al., 1997/2005). This can be regarded as the procurement part of consumer logistics which is defined as the efficient planning, organization, control as well as execution of the entire product and information flow arising between a point of sales, i.e. stores, and a point of consumption, e.g. households (Granzin and Bahn, 1989). When undertaking shopping endeavours in an agglomeration the customer can bundle several shopping tasks into one trip, thereby easing the burden of planning separate shopping trips, transportation and choosing of products (Oppewal and Holyoake, 2004). Thus this leads to reducing time, minimizing monetary or psychological costs and rationalizing the effort needed to fulfil the shopping task of procuring products (Bacon, 1995; Bell et al., 1998). This phenomenon has been investigated by several authors under the theme of multi-purpose shopping (e.g. Gosh 1986; Oppewal and Holyoake, 2004; Arentze and Timmermans, 2001; Bacon, 1995; Baker, 2006). As a consequence, attributes of agglomerations such as accessibility, distance to overcome to get to them and parking concerns can attract utilitarian shoppers (Kim, 2002). 
Table 2: Typology of agglomeration effects

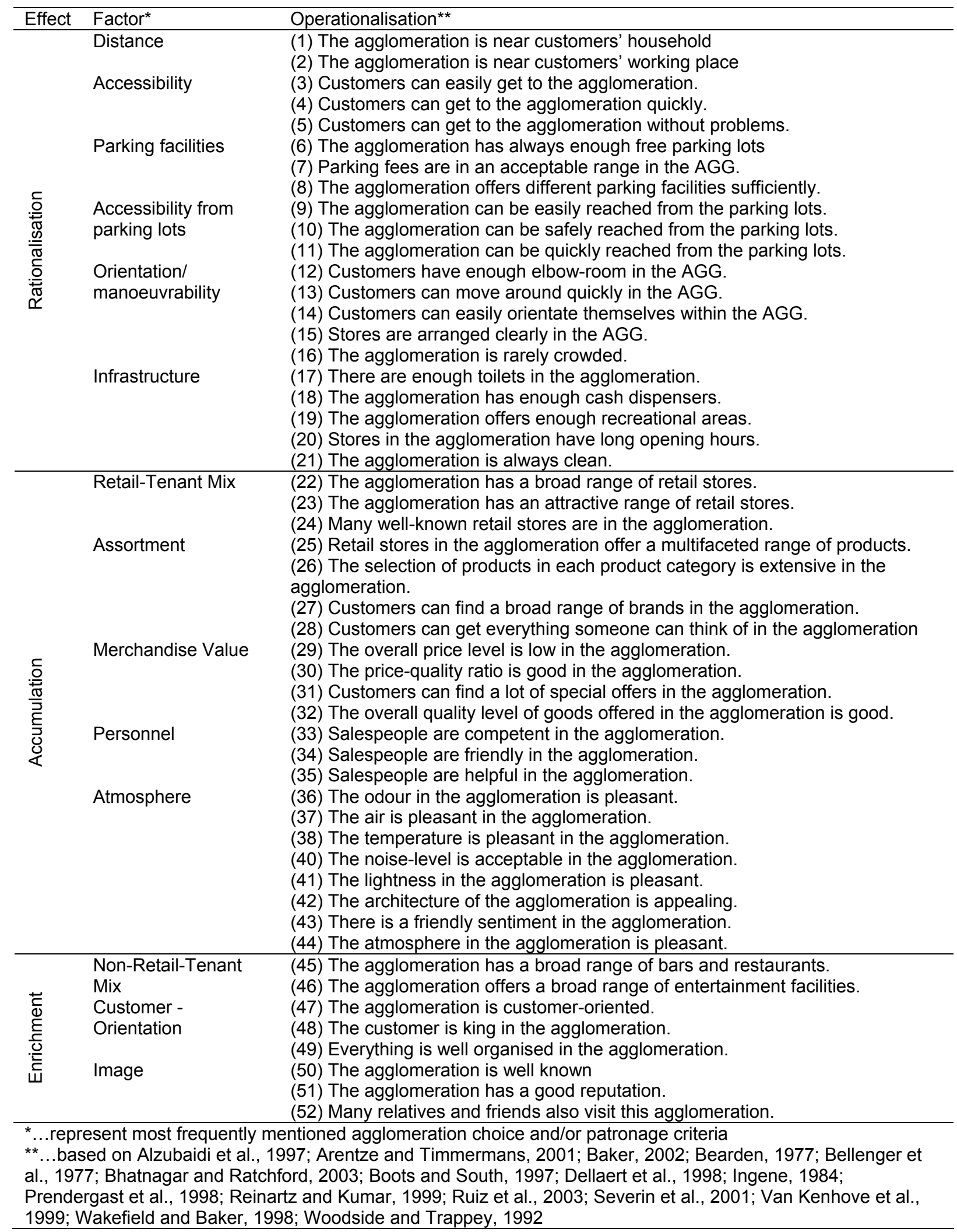




\section{Accumulation-Effect}

Agglomeration customers are confronted with a set of nearby stores offering different kinds of assortments. This provides the opportunity to satisfy bundles of wants and needs in one location. The variety and mix of shops, the breadth and depth of assortments and the merchandise value (price level, price-quality ratio) can result in a synergetic effect for customers who can gain an additional benefit from this accumulation of retail stores (Bacon, 1995). This leads to a unique retail profile of agglomerations and to an independent image. This also results in an atmosphere created by the agglomeration as a whole (e.g. Bellenger et al., 1977; Alzubaidi et al., 1997). Thereby, hedonists can be attracted by the presence of supra-store atmospheric, service, product or price stimuli. Furthermore, utilitarians are attracted by a high probability of satisfying wants and needs at agglomerations with a minimum of effort (Kim, 2002).

\section{Enrichment-Effect}

Apart from the core value of shopping, agglomerations offer other facilities or events that add benefits to customers. They also contain non-retail tenants like bars, restaurants, cinemas (Prendergast et al., 1998). In addition to that, events take place such as fashion shows, exhibitions etc., which provide entertainment to customers (Arnold and Reynolds, 2003). Agglomerations may also include recreational areas to relax or simply spend time in and, therefore, satisfy social needs (e.g. Rintamäki et al., 2006). Nevertheless, like shopping for single products and single stores the agglomeration shopping experience can also in itself appeal to hedonists (Langrehr, 1991). In fact, agglomerations are not only a place where goods are exchanged for money but also a "premier habitat for consumers" (Swinyard, 1998; Bloch et al., 1994). Finally, it should be mentioned that customers feel comfortable or pampered when they recognise an overall customer orientation which may be the output of several agglomeration marketing actions, for example provision of an orientation system or good infrastructure. This may also be recognised as enrichment of the shopping trip and so attract both shopper types discussed. Furthermore, the official legitimisation of a shopping 
site due to its publicity or due to the fact that relatives or friends, etc. also shop there may satisfy social needs. This, consequently, introduces a hedonic dimension of agglomerations.

We can conclude that agglomerations are more than the sum of their parts and so offer additional (hedonic and utilitarian) attractions for consumers compared to single store locations.

\section{CONCEPTUAL FrameWORK AND HyPOTHESES}

Based on Finn and Louviere (1996) and Teller and Reutterer (2007) the perception and evaluation of retail agglomerations from a customer perspective is determined by their basic characteristics or attributes. These characteristics are built up by the applied marketing mix such as location, accessibility, tenant mix, atmosphere, pricing, communication etc., which prove to be different across diverse kinds of agglomeration formats, in particular evolved and created ones. As a consequence, the agglomeration attractiveness is evaluated based on these perceptions which results in behavioural consequences, such as overall patronage, the number of visits per period of time, the number of shops visited per trip, the retention time etc..

As an extension of this conceptual frame, psychographic variables in terms of utilitarian and hedonic shopping orientation are considered. According to Kim (2002) an impact on the perception of agglomerations' characteristics, the evaluation of attractiveness and behavioural consequences is proposed (see Table 3). This impact can be observed and measured by (significant) differences between hedonic and utilitarian customer groups. Thus hedonists and utilitarians are attracted by agglomerations in different ways and consequently have a different kind of shopping behaviour on site. 
Table 3: Impact of shopping orientation on the evaluation of retail agglomerations and resulting behavioural consequences

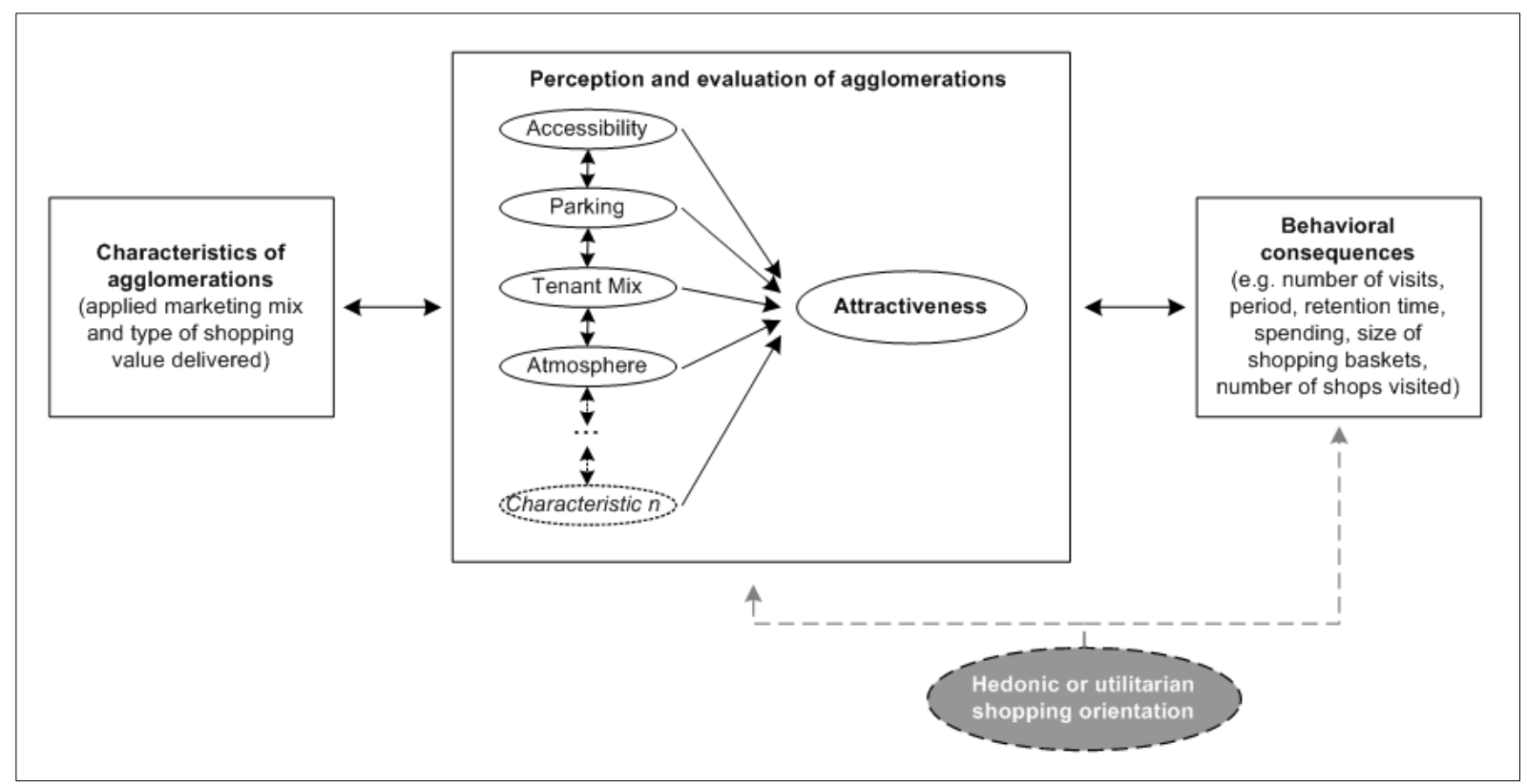

In order to identify whether there is such an impact on the variables considered in our framework we propose the following hypotheses:

As a first step, the question arises as to whether hedonic and utilitarian shopper types can be found in every demographic group to the same degree when looking at customers of retail agglomerations. With respect to the notions of Arnold and Reynolds (2003) or Campbell (1997) the first hypothesis is:

$H_{1}$ : Utilitarian customers differ significantly from hedonic customers with respect to their demographic characteristics.

Such demographic profiles typically include variables like gender, age, educational level, profession, number of persons in households or individual or household income (Berman and Evans, 2007). By identifying significant differences, hedonic and utilitarian customer types can be described in more detail based on their demographics, which as a result answers the crucial question for retail management as to which of the two groups is more attractive with respect to their purchasing power, time available for shopping or mobility. 
According to the notions of Alzubaidi et al. (1997) and Kim (2006) and the discussion of shopping values sought by consumers and provided by retail agglomerations we expect a difference in patronage towards evolved and created agglomerations of different customer types:

$H_{2}$ : The share of hedonic customers is significantly higher in shopping streets compared to shopping malls.

This hypothesis focuses on a major behavioural consequence, i.e. retail patronage, resulting from agglomerations' perception and evaluation (see Table 3). It focuses on the fact that utilitarian shoppers are confronted with several obstacles when satisfying their demand in shopping streets. Generally speaking the shopping trip is less convenient since parking spaces are limited, the accessibility by car is problematic owing to traffic infrastructure in inner cities and the shops sought are more difficult to find due to their unplanned/random location. In contrast to that a shopping trip to created and centrally-managed agglomerations can be far more convenient. This is due to the (mostly) peripheral location, the provision of (cost-free) parking facilities and orientation systems for customers.

Nevertheless, the recent shopping centre/mall concept comprises a combination of shopping and entertainment which should be more attractive for hedonists (e.g. Dennis, 2005). Customers of shopping streets may also be attracted by the architecture and pleasant ambience (Alzubaidi et al., 1997).

The next hypothesis $\mathrm{H}_{3}$ follows the notions of Alzubaidi et al. (1997), Kim (2002), Kim (2006) or Kang and Kim (1999) who conclude that hedonic and utilitarian customer types show a different type of shopping behaviour:

$H_{3}$ : The shopping behaviour in retail agglomerations of hedonic customers is significantly different to those of utilitarian customers.

Important variables operationalising shopping behaviour in retail agglomerations are among others - visiting frequency, number of stores visited per trip, retention time or spending per visit (Berman and Evans, 2007). Similar to demographic characteristics, 
differences in shopping behaviour may indicate a different attractiveness of hedonic or utilitarian customer groups for retail management. As a result, the investigation of this relationship of variables answers the question of whether psychographic orientation impacts the buying behaviour in agglomerations.

Finally, we look at differences regarding the attraction of agglomerations characteristics with respect to hedonists and utilitarians $\left(\mathrm{H}_{4}\right)(\mathrm{Kim}, 2002$; Rintamäki et al., 2007; see Table 2):

$\mathrm{H}_{4}:$ Hedonic customers are attracted by different agglomeration characteristics compared to utilitarian customers.

In other words, we investigate the impact of the shopping orientation on the perception and evaluation of agglomerations and as a consequence agglomeration patronage of hedonic and utilitarian customers.

In total, our hypotheses aim to investigate not only differences between hedonic and utilitarian customers in retail agglomerations but also differences between these groups in evolved and created retail agglomerations. Following this they shed light on the relevance of the proposed psychographic taxonomy for retail management in general and agglomeration and retail management of (a different kind of) agglomeration formats in particular.

\section{EMPIRICAL RESEARCH APPROACH}

\section{Basic Considerations}

Most researchers conducting empirical studies on agglomeration patronage issues apply the survey approach by using self-administered questionnaires which are completed in respondents' homes and draw random or stratified (based on census demographic structures) samples. This might lead to biased results due to 'role allocations' within households (cf. Sheth et al., 1999; Granzin et al., 1997). For example, respondents whose major role within a household is that of 'payer' or 'user' might be over-represented, whereas 
household members who are actually responsible for pursuing the actual shopping trip (and make the final decision on where to shop) are not included to a proper degree.

The current empirical study addresses these issues by offering an alternative approach. Similar to the attempt pursued by Bloch et al. (1994) the basic idea is to confront respondents with questions about the agglomeration they have actually chosen to satisfy their needs. Thus, our respondents were exposed to a more biotic or in-vivo interview environment and thereby have selected only those informants who exhibit a certain minimum degree of knowledge about the visited retail site (Campbell, 1955). In other words, to enhance internal validity of our empirical findings, people were not asked about what they plan to do hypothetically (i.e., before they choose a retail agglomeration) but we investigate how they evaluate their shopping orientation (hedonic and utilitarian), their shopping behaviour on site (in general) and how they perceive the respective agglomeration characteristics.

According to the research issue two different types of retail agglomerations were selected, namely a peripheral shopping mall (MAL; 'Shopping City Süd') and an inner-city shopping street (SST; 'Mariahilferstrasse') in Vienna. Both agglomerations represent the largest retail agglomerations in that retail area and are among the largest in Europe in terms of reported sales figures. They compete for the same supra-regional clientele with a comparable tenant mix which comprise the same set of pan-European anchor stores including Hennes \& Mauritz, Mediamarkt/Saturn, Mango, Zara, Peek \& Cloppenburg. Thus, inter-location store heterogeneity can be regarded as being limited with the consequence that the two selected retail agglomerations can be seen as being comparable with respect to their competitive standing in the relevant market. Such competition between created (shopping centres, malls) and evolved agglomerations (inner city shopping areas or shopping streets) within major urban areas can be considered as typical in many other geographical retail areas. 
To ensure comparability, survey instruments were synchronised in the two retail agglomerations under study. Respondents were recruited independently as random samples based on a time sampling procedure. To prevent respondent selection bias, following the arguments of Sudman (1980), three sampling points (entrances of the shopping mall, underground exits and parking lots in the shopping street) were selected in each agglomeration. At each of these points, customers were invited for interviews every quarter of an hour, whereas their number varied according to the time of day (Sudman, 1980). This procedure resulted in two representative samples of agglomeration clientele over a period of three weeks.

\section{Sample Characterisation}

Due to the sampling procedure employed the collected samples are representative of the agglomerations' clientele but do not necessarily reflect the demographic structure of the respective trading areas. Vienna differs from the retail market investigated by Kim (2006) and is represented by consumers who are more educated and have a higher level of income compared to the rest of the country.

Table 4: Demographic and behavioural characterisation of respondents

\begin{tabular}{|c|c|c|c|}
\hline Demographic and behavioural characterisation & $\begin{array}{c}\text { Shopping Street } \\
\text { (SST) }\end{array}$ & $\begin{array}{l}\text { Shopping Mall } \\
\text { (MAL) }\end{array}$ & $\begin{array}{c}\text { Differences } \\
\text { between clientele }\end{array}$ \\
\hline $\begin{array}{l}\text { Age (years) }[\mu(\sigma)]^{2} \\
\text { Income Indiv (EUR) }[\mu(\sigma)]^{2} \\
\text { Income hh (EUR) }[\mu(\sigma)]^{2} \\
\text { \# of persons in hh }[\mu(\sigma)]^{2} \\
\text { Gender (\% female) } \\
\text { Education } \\
\text { Top } 3(\%)^{1}\end{array}$ & $\begin{array}{c}27.31(12.87) \\
905.06(886.31) \\
2,489.84(1,995.89) \\
2.64(1.62) \\
62.7 \% \\
A=45.1 \% \\
S=23.6 \% \\
U=17.1 \% \\
\end{array}$ & $\begin{array}{c}30.66(13.64) \\
1151.59(1102.34) \\
2,789.92(1,896.33) \\
2.82(1.6) \\
61 \% \\
A=37.2 \% \\
S=29.5 \% \\
U=11.6 \%\end{array}$ & $\begin{array}{c}* * \\
* * * \\
* * * \\
* * \\
- \\
* * *\end{array}$ \\
\hline Shopping (visiting) frequency per month $[\mu(\sigma)]^{2}$ & $5.05(7.02)$ & $2.68(4.47)$ & *** \\
\hline Spending (EUR) per visit $[\mu(\sigma)]^{2}$ & $65.09(77.82)$ & $112.45(155.93)$ & $* * *$ \\
\hline Retention time $(\min )$ per visit $[\mu(\sigma)]^{2}$ & $140.45(81.35)$ & $164.89(88.61)$ & *** \\
\hline Shops visited per trip on average $[\mu(\sigma)]^{2}$ & $3.71(3.15)$ & $4.57(3.86)$ & $* * *$ \\
\hline \multicolumn{4}{|c|}{ 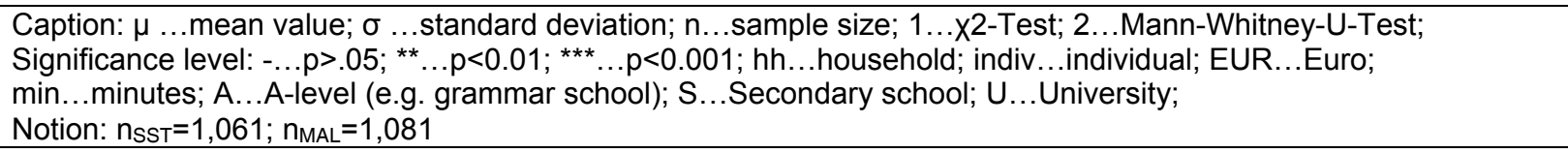 } \\
\hline
\end{tabular}


Our respondents can be considered as young (see Table 4). As expected, female shoppers dominate each sample. Both income and educational level are above average. The individual (net) income of respondents is slightly below average (Statistik Austria, 2007). Overall, apart from gender, both samples significantly differ with respect to demographic variables.

Furthermore, significant differences in terms of shopping/visiting frequencies per month, average expenditure per trip, number of shops visited per trip and retention time per visit were noticed. As a result, it can be concluded that the respondents in the shopping mall shop less frequently but spend more time there, visiting more shops and spending more money per trip. We are obviously confronted with two quite heterogeneous groups of respondents who show a different form of shopping behaviour on site.

\section{FINDINGS}

\section{Identification of Shopper Types}

Measurement Scale and Typology Construction

The above-described tendency of shoppers to vary along the stereotypes of a hedonic vs. utilitarian orientation was measured using a slightly adapted version of a multi-item scale developed by Babin et al. (1994). The measurement instrument consisted of 13 items indicating a more hedonic orientation, and 6 items indicating a more utilitarian shopping orientation of respondents (see Table 12 in the appendix for a complete list of the scale employed in the present study). These ratings refer to a general orientation of when our respondents shop. We therefore neglect a variation of shopping values along with different shopping situations.

The task of converting this measurement scale into a typology that adequately reflects the various notions of empirically observable shopping orientation tendencies requires a data compression step. The objective of this data condensing approach is to substitute the 
complete set of 19 indicators by a newly introduced categorical feature variable. This feature variable represents symptomatic patterns of hedonic vs. utilitarian shopping value indicators and is responsible for assigning each respondent to one of the shopping value types. Considering the high inter-item correlations within the two subsets of shopping value indicators (corresponding to Cronbach's $\alpha$ are .938 for the hedonic and .62 for the utilitarian value item subsets), an approach that accounts for this specific covariance structure was needed. Thus, we employ an extension of the standard fuzzy c-means clustering algorithm (e.g. Bezdek, 1981) which was initially introduced by Gustafson and Kessel (1979). In order to allow for the detection of clusters with different geometrical shapes in one data set, the iterative GK (Gustafson-Kessel) algorithm utilises an adaptive re-weighting scheme of the cluster-specific covariance matrices that provides a generalised squared Mahalanobis distance norm between each data point and respective cluster means. In the present application, a numerically robust version of the GK algorithm described by Babuska et al. (2002) was used to estimate the fuzzy membership matrices for an increasing number of clusters.

As a heuristic to determine an appropriate number of clusters, which corresponds to the derived typology of shopping value tendencies in the present context, the "weighted simple structure index" (wSSI) proposed by Mazanec and Strasser (2000) was computed for a sequence of $c=2, \ldots, 15$ partitions. Defuzzification of the membership values was accomplished by taking the respective maximum values from the fuzzy membership matrices generated by the GK algorithm. Similar to the concept of the well-known "silhouette coefficient" (eg. Kaufman and Rouseeuw, 2005), the wSSI is a heuristic measure of the distinctive quality of cluster profiles, which previously proved to be a useful instrument for determining the 'correct' number of clusters in a number or simulation experiments (e.g. Dimitriadou et al., 2002). While the (unweighted) SSI takes only the contrast between representative cluster-specific mean profiles into account, the wSSI also penalises the exuberance of an increasing number of clusters. 
When plotting the two measures against each other for increasing number of clusters the wSSI clearly recommends a four-cluster solution. Hence further investigation of a typology of shopping value tendencies derived by the four-cluster solution is advisable and will be discussed in more detail in the following subsection.

\section{Description of Clusters}

Both the choice of number of and interpretation of the single clusters are based on the fact that consumers have either a more hedonic or/and utilitarian orientation towards shopping in general (Babin et al., 1994)., We avoid therefore applying a black and white perspective by identifying not only two stereotypes. Thus, we consider the notions of Westbrook and Black (1985) who address the duality of shopping orientation of every consumer on the one hand but suggest a preference towards one of the two attitudes on the other hand. By doing so, we see the need for including the 'shades of grey'.

Table 5 shows the four clusters which can be characterised by the mean values of variable ratings included in the cluster analysis (see the snake charts in Table 5). The interpretation can be supported by a visual inspection of the cluster-specific mean values compared to the overall means ( $n=2,139$; see the bar charts). Indications of the statistical significance of differences between the ratings across the four groups can be retrieved from Table 12 in the appendix. 
Cluster 1 (pure hedonists)

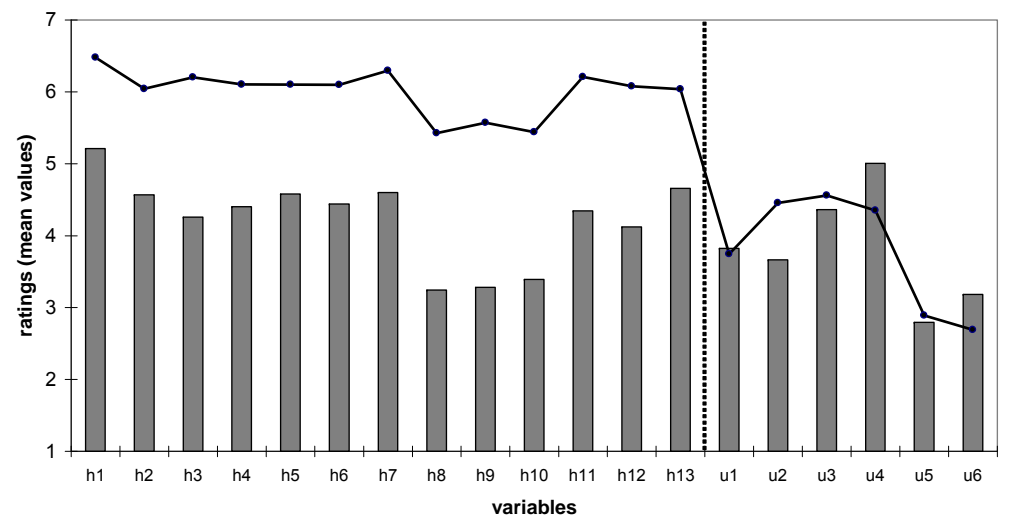

Cluster 3 (slight utilitarians)

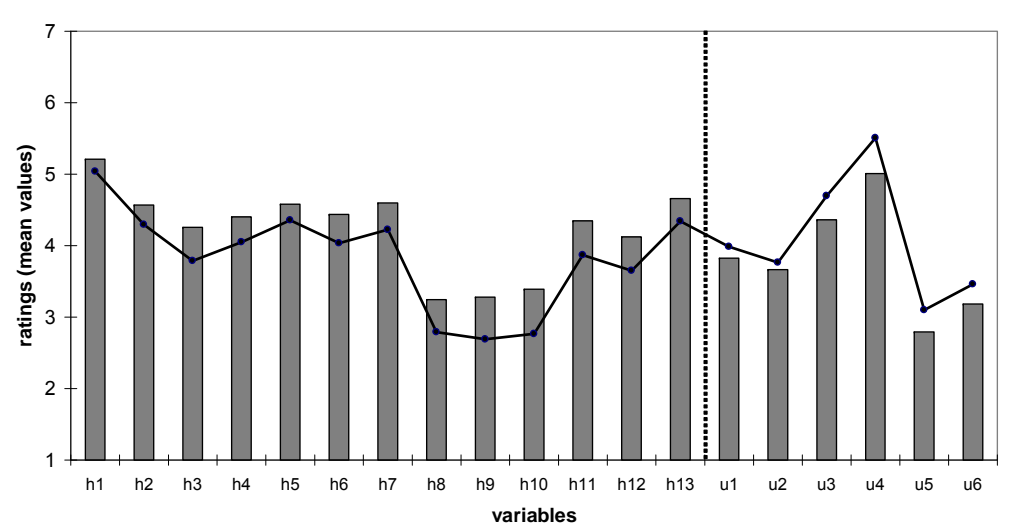

Caption: $\quad . .$. mean values of the total sample

$\ldots \ldots$... within-cluster mean values

Notions:

- The operationalization of the variables $\mathrm{h} 1-13$ and $\mathrm{u} 1-\mathrm{u} 6 \mathrm{can}$ be seen from the appendix. The variables $h$ describe a hedonic and $u$ a utilitarian shopping orientation - The results are based on a 7-point rating scale ( $1=$ do not aggree, $7=$ totally aggree)

- Sizes of clusters: $\mathrm{pH}=518 ; \mathrm{sH}=442 ; \mathrm{sU}=716 ; \mathrm{pU}=463 ; \mathrm{n}=2,139$
Cluster 2 (slight hedonists)

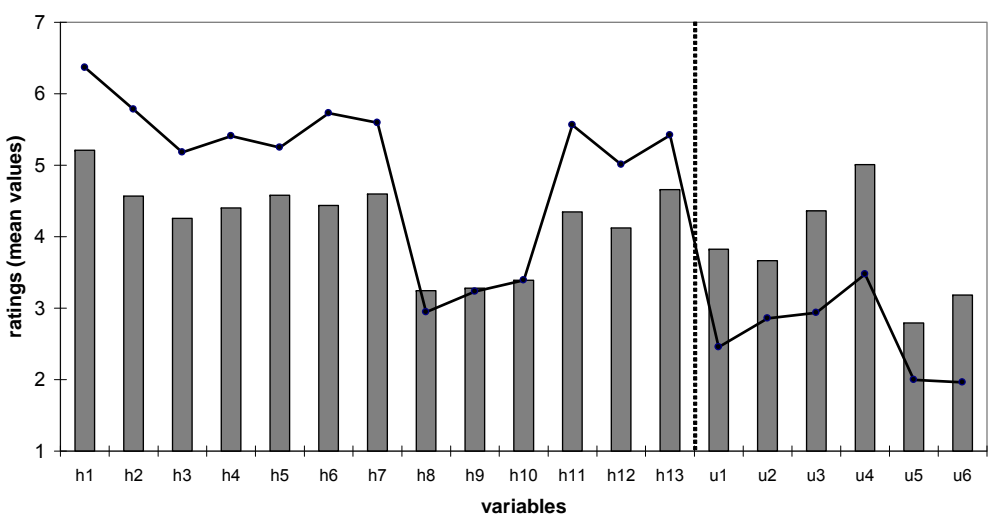

Cluster 4 (pure utilitarians)

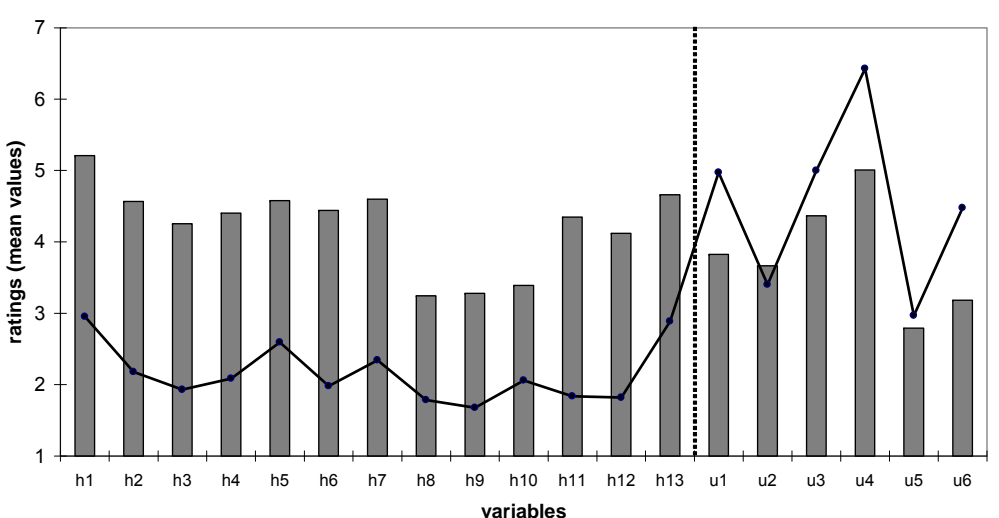


Cluster $1(24.2 \% ; n=2,139)$ represents a group of respondents that rate all variables operationalising hedonic shopping orientation (h1-h13) significantly higher compared to the other three groups. In contrast to that, the utilitarian variables (u1-6) are rated in line with the sample average values. Therefore, customers belonging to this group can be called 'pure hedonists' $(\mathrm{pH})$. Cluster $2(20.7 \% ; n=2,139)$ shows a similar general pattern. The hedonic ratings are, however, in total lower than in group ' $\mathrm{pH}$ ' with respect to the items h8-10 (feel excitement, forget problems, feel adventure while shopping) - but show the lowest results with respect to the utilitarian shopping orientation. Since these customers are less hedonic oriented than $\mathrm{pH}$ and less utilitarian oriented than the rest of the three groups we denote them as 'slight hedonists' (sH).

The members of cluster $3(33.5 \% ; n=2,139)$ show a less hedonic shopping orientation than $\mathrm{pH}$ and $\mathrm{sH}$. Except variable $\mathrm{u} 2$ (cannot find what they are looking for) these customers regard shopping as "work" (Babin, et al., 1994) or as inconvenient. Following this description, the last cluster $(4 ; 21.6 \% ; n=2,139)$ can be interpreted as being much more extreme by experiencing less hedonic but more utilitarian shopping values. That means the hedonic ratings are the lowest of all four groups and most utilitarian ratings (except u2 and u5) are the highest. By comparing the two groups with respect to $\mathrm{pH}$ and $\mathrm{sH}$ we call the more moderate one (cluster 3) 'slight utilitarians' (sU) and the more extreme or stereotypical one 'pure utilitarians' $(p U)$.

Finally, we should stress that none of the clusters show the precise representation of hedonists and utilitarian shoppers mentioned in literature. As a result, the duality of both orientations within each group seems to be evident.

\section{Hypotheses Testing}

To test our hypotheses we first compare demographic and behavioural variables between the identified shopper types by applying $x^{2}$-Tests for dichotomous scaled variables and 
Mann-Whitney U-Tests for metric-scaled variables. For the sake of simplicity we first look at the differences between shopper types which are hedonically or utilitarianly oriented in general, i.e. we merge the identified four groups $(\mathrm{pH}, \mathrm{sH}, \mathrm{sU}$ and $\mathrm{pU})$ into two $(\mathrm{H}$ and $U)$. Thereafter, we enlarge on differences between the four groups in more detail.

$H_{1}$ : Utilitarian customers differ significantly from hedonic customers with respect to their demographic characteristics.

To compare the single groups we applied commonly-used demographic indicators which can be seen from Table 6 (Berman and Evans, 2007). Hedonists $(H)$ show significantly different demographic characteristics when looking at those variables focusing on the individual but not the household level. In other words, hedonic customers are more often female, younger, have less individual net-income, spend less time at work, are less educated and include a higher share of senior citizens compared to utilitarian ones. Interestingly, no significant differences can be identified regarding the size of households and the availability of cars in households. Individual net-income represents the amount of money which is available for the single person. This does not mean that the respondents are only 'allowed' or 'designated' to spend their own available money and are only responsible for buying goods and services for them. Thus, our shoppers can undertake the procurement task, i.e. the shopper's role in households, for other persons. This fact should be considered when interpreting the spending behaviour when testing $\mathrm{H}_{3}$.

When searching for significant differences between the four groups it can be concluded that we face a similar picture with respect to $\mathrm{pH}$ and $\mathrm{pU}$. The hybrid shopper groups, i.e. $\mathrm{sH}$ and $\mathrm{sU}$, do not show a particular demographic characterisation. Nevertheless, this is not true for the groups which have the same or a similar psychographic orientation. This leads to the conclusion that $\mathrm{sH}$ and $\mathrm{sU}$ build up a more homogenous group with each other than the two pure shopper types do with any other group. 
Finally, we conclude that $\mathrm{H}_{1}$ can be accepted whereas hedonic shopper types are time-rich but cash poor in contrast to utilitarians when looking at demographic variables describing the customer as an individual and not as part of a household community.

Table 6: Demographic characterisation of shopper types

\begin{tabular}{|c|c|c|c|c|c|c|c|c|c|c|c|}
\hline \multirow[b]{2}{*}{$\begin{array}{l}\text { Demographic } \\
\text { characterisation }\end{array}$} & \multicolumn{4}{|c|}{ Shopper types } & \multicolumn{7}{|c|}{ Differences between groups } \\
\hline & $\begin{array}{l}\text { Pure } \\
\text { hedonists } \\
(\mathrm{pH})\end{array}$ & $\begin{array}{l}\text { Slight } \\
\text { hedonists } \\
(\mathrm{sH})\end{array}$ & $\begin{array}{l}\text { Slight } \\
\text { utilitarians } \\
\text { (sU) }\end{array}$ & $\begin{array}{l}\text { Pure } \\
\text { utilitarians } \\
(p U)\end{array}$ & $\begin{array}{l}\stackrel{\supset}{\uparrow} \\
\underline{1}\end{array}$ & $\begin{array}{l}\frac{T}{0} \\
1 \\
\frac{1}{2}\end{array}$ & $\begin{array}{l}\supset \\
\infty \\
\frac{1}{\infty}\end{array}$ & $\begin{array}{l}\vec{\partial} \\
\frac{0}{1} \\
\stackrel{2}{\omega}\end{array}$ & $\begin{array}{l}\supset \\
\infty \\
1 \\
\frac{1}{2}\end{array}$ & $\begin{array}{l}\frac{\supset}{1} \\
\frac{1}{\infty}\end{array}$ & $\begin{array}{l}? \\
\stackrel{0}{1} \\
\frac{1}{2}\end{array}$ \\
\hline $\begin{array}{l}\text { Gender }(\% \\
\text { female })^{1}\end{array}$ & $73.3 \%$ & $72.9 \%$ & $56.6 \%$ & $46.1 \%$ & $* * *$ & - & *** & $* *$ & $* * *$ & $* * *$ & *** \\
\hline $\begin{array}{l}\text { Age (years) } \\
{[\mu(\sigma)]^{2}}\end{array}$ & $27.7(14.7)$ & $27.7(12.6)$ & $28.8(12.5)$ & $31.9(13.4)$ & $* * *$ & - & * & $* * *$ & $* * *$ & $* * *$ & *** \\
\hline $\begin{array}{l}\text { Income Indiv } \\
\left(\text { EUR) }[\mu(\sigma)]^{2}\right.\end{array}$ & $\begin{array}{l}796.1 \\
(813.4)\end{array}$ & $\begin{array}{c}984.1 \\
(981.7)\end{array}$ & $\begin{array}{l}1,029.5 \\
(954.9)\end{array}$ & $\begin{array}{c}1,335.6 \\
(1212.8)\end{array}$ & $* * *$ & ** & - & $* * *$ & $* * *$ & $* * *$ & *** \\
\hline $\begin{array}{l}\text { Income hh } \\
\left(\text { EUR) }[\mu(\sigma)]^{2}\right.\end{array}$ & $\begin{array}{l}2,627.8 \\
(2,094.9)\end{array}$ & $\begin{array}{l}2,623.8 \\
(1,796)\end{array}$ & $\begin{array}{c}2,614.8 \\
(1,794.6)\end{array}$ & $\begin{array}{c}2,731.3 \\
(2,169.7)\end{array}$ & - & - & - & - & - & - & - \\
\hline $\begin{array}{l}\text { \# of persons } \\
\text { in } \mathrm{hh}[\mu(\sigma)]^{2}\end{array}$ & $2.9(1.7)$ & $2.6(1.4)$ & $2.7(1.5)$ & $2.6(1.9)$ & - & $* * *$ & * & - & * & - & *** \\
\hline $\begin{array}{l}\text { \# of cars } \\
\text { available in hh } \\
{[\mu(\sigma)]^{2}} \\
\text { Working hours } \\
\text { per week }[\mu(\sigma)]^{2}\end{array}$ & $19.9(20)$ & $22.9(21)$ & $24.3(29.1)$ & $28.6(36.7)$ & $* * *$ & * & - & ** & ** & $* *$ & $* * *$ \\
\hline $\begin{array}{l}\text { Education } \\
\text { Top } 3(\%)^{1}\end{array}$ & $\begin{array}{c}S=41.7 \% \\
A=33.1 \% \\
V S=11.3 \% \\
\end{array}$ & $\begin{array}{l}A=43.7 \% \\
S=24.2 \% \\
U=11.7 \%\end{array}$ & $\begin{array}{c}A=44.1 \% \\
S=24.1 \% \\
U=15 \%\end{array}$ & $\begin{array}{l}A=42.8 \% \\
U=24.3 \% \\
S=16.3 \%\end{array}$ & $* * *$ & $* * *$ & - & ** & $* * *$ & $* * *$ & $* * *$ \\
\hline $\begin{array}{l}\text { Caption: } \mu \text {...mear } \\
\text { level: }-. . . p>.05 ;{ }^{*} . . \\
\text { A...A-level (eg. gr } \\
\text { Notion: } n_{\mathrm{SST}}=1,06\end{array}$ & $\begin{array}{c}\text { value; } \sigma \ldots \mathrm{st} \\
0<0.05 ;{ }^{* *} \ldots \mathrm{p} \\
\text { nmar school } \\
\mathrm{n}_{\mathrm{MAL}}=1,073\end{array}$ & $\begin{array}{l}\text { lard deviatio } \\
01 ;{ }^{* * *} \ldots p<0 \\
\ldots \text { Secondar } \\
\text { e also Table }\end{array}$ & $\begin{array}{l}\text { n...sample s } \\
01 ; \text { hh...hous } \\
\text { chool; U...U }\end{array}$ & $\begin{array}{l}1 \ldots \times 2-T e s t \\
\text { old; indiv...i } \\
\text { ersity; VS... }\end{array}$ &.. $\mathrm{M}$ & $\mathrm{nn}-\mathrm{V}$ & 11 & $1 T$ & t; Sig & ifica & \\
\hline
\end{tabular}

$\mathrm{H}_{2}$ : The share of hedonic customers is significantly higher in shopping streets compared to shopping malls.

Based on the fact that hedonic and utilitarian shoppers are different with regard to their demographic characteristic the distribution of our shopper types in distinct agglomerations is compared. Both samples are dominated by $\mathrm{sU}$ whereas $\mathrm{sH}$ represent the smallest groups (see Table 7). The second largest groups belong to different types in the two investigated agglomerations. In total, hedonists can be found to a significantly higher degree in the MALL (49.5\%) compared to the SST (40.2\%). Therefore, we have to reject $\mathrm{H}_{2}$. 
The investigated shopping sites appeal to different groups in general and with respect to their shopping orientation in particular. Being aware of the fact that the retail tenant-mix and the price/quality level are quite similar in both the investigated agglomerations other attributes of the two agglomerations come into play. These distinguishing factors may result from other basic differences of created and evolved agglomerations. Consequently, such perceived agglomeration effects (see Table 2) attract different customer groups. The results may indicate the comparably high hedonic attraction of the created agglomerations compared to evolved ones (Kim, 2002). Thus, the clientele effect regarding retail agglomerations can be observed and the moderating effect of the investigated psychographic orientation toward retail patronage can be confirmed.

From a retail management point of view the question must be asked as to what kind of value is delivered by the specific shopping destination since this leads to the establishment of a clientele. We would call this phenomenon Say's law of retailing: Every supply, i.e. retail store or agglomeration, creates its demand, i.e. specific customer group. The respective customer group can be described selectively not only by their demographics but also by their psychographic orientation.

Table 7: Distribution between shopper types in investigated agglomerations

\begin{tabular}{|c|c|c|c|c|c|c|}
\hline Shopper types & $\begin{array}{l}\text { Hedonists } \\
(\mathrm{H})\end{array}$ & $\begin{array}{l}\text { Utilitarians } \\
\text { (U) }\end{array}$ & $\begin{array}{c}\text { Pure } \\
\text { hedonists } \\
(\mathrm{pH})\end{array}$ & $\begin{array}{c}\text { Slight } \\
\text { hedonists } \\
(\mathrm{sH})\end{array}$ & $\begin{array}{l}\text { Slight } \\
\text { utilitarians } \\
(\mathrm{sU})\end{array}$ & $\begin{array}{c}\text { Pure } \\
\text { utilitarians } \\
(p U)\end{array}$ \\
\hline Shopping mall (MALL) & $49.5 \%$ & $50.5 \%$ & $28.8 \%$ & $20.7 \%$ & $32.1 \%$ & $18.4 \%$ \\
\hline Shopping street (SST) & $40.2 \%$ & $59.8 \%$ & $19.6 \%$ & $20.6 \%$ & $34.9 \%$ & $24.9 \%$ \\
\hline
\end{tabular}

$H_{3}$ : The shopping behaviour in retail agglomerations of hedonic customers is significantly different to those of utilitarian customers.

Since we identified a varying preference of different shopper types towards agglomerations we investigate whether hedonists and utilitarians show a distinctive shopping behaviour. Referring to the results from $\mathrm{H}_{1}$ we see a similarly clear picture. All chosen variables 
operationalising important characteristics of shopping behaviour (Berman and Evans, 2007) prove to be significantly different between $\mathrm{H}$ and $\mathrm{U}$. Hedonists shop more often in general and specifically in the investigated agglomerations, they spend more money on food and entertainment and remain there for a longer period of time and consequently visit more stores compared to utilitarian shoppers. When looking at the total expenditure per month (=average shopping frequency per month * (expenditures for goods/services + food/entertainment)) we can conclude that hedonic shoppers represent a higher propensity to spend money in agglomerations.

When looking at differences between the four groups again, we see a clear differentiation between the two pure shopper types $(\mathrm{pH}$ and $\mathrm{pU})$ and a more homogenous character of the two moderate types in both retail settings. The most selective criteria prove to be the retention time and the number of stores visited. 
Table 8: Behavioural characterisation of shopper types in investigated agglomerations

\begin{tabular}{|c|c|c|c|c|c|c|c|c|c|c|c|}
\hline \multirow[b]{2}{*}{$\begin{array}{l}\text { Behavioural } \\
\text { characterisation }\end{array}$} & \multicolumn{4}{|c|}{ Shopper types } & \multicolumn{7}{|c|}{ Differences between groups ${ }^{1}$} \\
\hline & $\begin{array}{l}\text { Pure } \\
\text { hedonists } \\
(\mathrm{pH})\end{array}$ & $\begin{array}{l}\text { Slight } \\
\text { hedonists } \\
(\mathrm{sH})\end{array}$ & $\begin{array}{l}\text { Slight } \\
\text { utilitarians } \\
\text { (sU) }\end{array}$ & $\begin{array}{l}\text { Pure } \\
\text { utilitarians } \\
\quad(p U)\end{array}$ & $\begin{array}{l}\stackrel{\supset}{\perp} \\
I\end{array}$ & $\begin{array}{l}\frac{T}{w} \\
1 \\
\frac{1}{2}\end{array}$ & $\begin{array}{l}\supset \\
\text { I } \\
\frac{I}{\omega}\end{array}$ & $\begin{array}{l}\overrightarrow{2} \\
\frac{0}{1} \\
\text { ๖ }\end{array}$ & $\begin{array}{l}\text { D } \\
\hat{1} \\
\text { I } \\
2\end{array}$ & $\begin{array}{l}\frac{2}{a} \\
\frac{1}{1}\end{array}$ & $\begin{array}{l}? \\
\frac{0}{1} \\
\frac{1}{2} \\
0\end{array}$ \\
\hline \multicolumn{12}{|c|}{ Shopping street } \\
\hline $\begin{array}{l}\text { Shopping frequency in } \\
\text { general per month }[\mu \\
(\sigma)]\end{array}$ & $\begin{array}{l}13.8 \\
(7.4)\end{array}$ & $\begin{array}{l}13.7 \\
(7.7)\end{array}$ & $\begin{array}{l}12.8 \\
(7.5)\end{array}$ & $\begin{array}{l}11.3 \\
(7.1)\end{array}$ & $* * *$ & - & - & * & - & $* * *$ & $* * *$ \\
\hline $\begin{array}{l}\text { Shopping (visiting) } \\
\text { frequency per month } \\
{[\mu(\sigma)]}\end{array}$ & $\begin{array}{c}5.4 \\
(6.9)\end{array}$ & $\begin{array}{l}5.7 \\
(7.1)\end{array}$ & $\begin{array}{l}5.1 \\
(7.2)\end{array}$ & $\begin{array}{c}4.1 \\
(6.9)\end{array}$ & $* * *$ & - & - & ** & - & $* * *$ & $* * *$ \\
\hline $\begin{array}{l}\text { Expenditures on } \\
\text { products/services } \\
(\text { EUR) per visit }[\mu(\sigma)]\end{array}$ & $\begin{array}{l}77.1 \\
(76.8)\end{array}$ & $\begin{array}{c}73.6 \\
(100.2)\end{array}$ & $\begin{array}{c}57.6 \\
(63.9)\end{array}$ & $\begin{array}{c}59.2 \\
(73.7)\end{array}$ & $* * *$ & * & - & - & $* * *$ & * & $* * *$ \\
\hline $\begin{array}{l}\text { Expenditures on } \\
\text { food/entertainment } \\
(\text { EUR) per visit }[\mu(\sigma)]\end{array}$ & $\begin{array}{c}17.5 \\
(27.3)\end{array}$ & $\begin{array}{c}13.4 \\
(13.5)\end{array}$ & $\begin{array}{c}11.8 \\
(13.5)\end{array}$ & $\begin{array}{c}9.5 \\
(11.4)\end{array}$ & $* * *$ & - & * & $* *$ & $* *$ & $* * *$ & *** \\
\hline $\begin{array}{l}\text { Retention time }(\mathrm{min}) \\
\text { per visit }[\mu(\sigma)]\end{array}$ & $\begin{array}{c}174.3 \\
(84)\end{array}$ & $\begin{array}{l}161.1 \\
(86.5)\end{array}$ & $\begin{array}{l}133.6 \\
(78.7)\end{array}$ & $\begin{array}{l}106.2 \\
(61.2)\end{array}$ & $* * *$ & * & $* * *$ & $* \star *$ & $* * *$ & $* * *$ & $* * *$ \\
\hline $\begin{array}{l}\text { Shops visited per trip } \\
\text { on average }[\mu(\sigma)]\end{array}$ & $4.3(3.1)$ & $4.3(3.5)$ & $3.6(2.9)$ & $3(3)$ & $* * *$ & - & $* * *$ & $* * *$ & $* \star *$ & $* * *$ & $* * *$ \\
\hline \multicolumn{12}{|c|}{ Shopping mall } \\
\hline $\begin{array}{l}\text { Shopping frequency in } \\
\text { general per month }[\mu \\
(\sigma)]\end{array}$ & $\begin{array}{l}12 \\
(7)\end{array}$ & $\begin{array}{l}12.8 \\
(7.2)\end{array}$ & $\begin{array}{l}10.7 \\
(6.5)\end{array}$ & $\begin{array}{l}10.7 \\
(7.3)\end{array}$ & $* * *$ & - & $* *$ & - & * & $* *$ & * \\
\hline $\begin{array}{l}\text { Shopping (visiting) } \\
\text { frequency per month } \\
{[\mu(\sigma)]}\end{array}$ & $\begin{array}{c}3.5 \\
(5.3)\end{array}$ & $\begin{array}{l}2.9 \\
(4.9)\end{array}$ & $\begin{array}{c}2.4 \\
(3.7)\end{array}$ & $\begin{array}{c}1.6 \\
(3.4)\end{array}$ & $* * *$ & - & - & $* * *$ & * & $* * *$ & $* * *$ \\
\hline $\begin{array}{l}\text { Expenditures on } \\
\text { products/services } \\
(\text { EUR) per visit }[\mu(\sigma)]\end{array}$ & $\begin{array}{c}114.7 \\
(134.5)\end{array}$ & $\begin{array}{l}114.1 \\
(136)\end{array}$ & $\begin{array}{c}95.1 \\
(104.1)\end{array}$ & $\begin{array}{c}137.2 \\
(251.5)\end{array}$ & * & - & * & ** & ** & - & - \\
\hline $\begin{array}{l}\text { Expenditures on } \\
\text { food/entertainment } \\
(E U R) \text { per visit }[\mu(\sigma)]\end{array}$ & $\begin{array}{c}19.2 \\
(20.9)\end{array}$ & $\begin{array}{c}16.1 \\
(19.4)\end{array}$ & $\begin{array}{l}14.7 \\
(17)\end{array}$ & $\begin{array}{c}11.8 \\
(14.7)\end{array}$ & $* * *$ & $* *$ & - & * & $* * *$ & $* *$ & $* * *$ \\
\hline $\begin{array}{l}\text { Retention time (min) } \\
\text { per visit }[\mu(\sigma)]\end{array}$ & $\begin{array}{l}191.5 \\
(88.3)\end{array}$ & $\begin{array}{c}177.2 \\
(87)\end{array}$ & $\begin{array}{l}151.8 \\
(81.9)\end{array}$ & $\begin{array}{l}132.3 \\
(87.9)\end{array}$ & $* * *$ & * & $* * *$ & ** & $* * *$ & $* * *$ & $* * *$ \\
\hline $\begin{array}{l}\text { Shops visited per trip } \\
\text { on average }[\mu(\sigma)]\end{array}$ & $\begin{array}{l}5.7 \\
(5)\end{array}$ & $\begin{array}{c}4.9 \\
(3.5)\end{array}$ & $\begin{array}{c}4.1 \\
(3.2)\end{array}$ & $\begin{array}{c}3.4 \\
(2.7)\end{array}$ & $* * *$ & - & $* * *$ & $* *$ & $* * *$ & $* * *$ & *** \\
\hline
\end{tabular}

When comparing $\mathrm{H}$ and $\mathrm{U}$ between the SST and the MAL we see significant differences amongst all behavioural variables (see Table 9). This is also the case for all four shopper types whereas expenditure on food and entertainment are mostly similar in the two agglomerations. 
Table 9: Behavioural differences of shopper types with respect to the investigated agglomerations

\begin{tabular}{|c|c|c|c|c|c|c|}
\hline $\begin{array}{l}\text { Shopper types } \\
\text { Behavioural Characterisation }\end{array}$ & $\begin{array}{l}\text { Hedonists } \\
\text { (H) }\end{array}$ & $\begin{array}{l}\text { Utilitarians } \\
\qquad(U)\end{array}$ & $\begin{array}{c}\text { Pure } \\
\text { hedonists } \\
(\mathrm{pH})\end{array}$ & $\begin{array}{l}\text { Slight } \\
\text { hedonists } \\
\text { (sH) }\end{array}$ & $\begin{array}{l}\text { Slight } \\
\text { utilitarians } \\
(\mathrm{sU})\end{array}$ & $\begin{array}{l}\text { Pure } \\
\text { utilitarians } \\
\quad(p U)\end{array}$ \\
\hline $\begin{array}{l}\text { Shopping frequency in general } \\
\text { per month }[\mu(\sigma)]\end{array}$ & ** & $\star * * *$ & * & - & $\star \star * *$ & - \\
\hline $\begin{array}{l}\text { Shopping (visiting) frequency per } \\
\text { month }[\mu(\sigma)]\end{array}$ & $\star \star * *$ & $* * *$ & $\star * * *$ & $\star \star \star *$ & $\star * * *$ & $\star * * *$ \\
\hline $\begin{array}{l}\text { Expenditure on } \\
\text { products/services (EUR) per visit } \\
{[\mu(\sigma)]}\end{array}$ & $\star * *$ & $\star \star \star *$ & $\star \star * *$ & $\star \star \star *$ & *** & *** \\
\hline $\begin{array}{l}\text { Expenditure on } \\
\text { food/entertainment (EUR) per } \\
\text { visit }[\mu(\sigma)]\end{array}$ & ** & $* *$ & $\star *$ & - & - & - \\
\hline $\begin{array}{l}\text { Retention time }(\mathrm{min}) \text { per visit }[\mu \\
(\sigma)]\end{array}$ & ** & $* * *$ & * & * & $* *$ & $* *$ \\
\hline $\begin{array}{l}\text { Shops visited per trip on average } \\
{[\mu(\sigma)]}\end{array}$ & 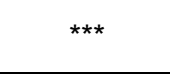 & $\star \star \star *$ & $\star \star \star *$ & ** & *** & $\star \star * *$ \\
\hline
\end{tabular}

By accepting $\mathrm{H}_{3}$ we may conclude that again a clientele effect can be investigated not only with respect to demographic characterisation but also towards shopping behaviour. This supports the notions of Westbrook and Black (1985), who suggest that a retailer should take such psychographic orientation into account as this is relevant for defining target groups and/or refining the retail strategy toward the needs of existing and prospective customers.

$\mathrm{H}_{4}:$ Hedonic customers are attracted by different agglomeration characteristics compared to utilitarian customers.

Finally, we want to investigate what role different attributes of the two distinct shopping sites have for patronage. Our respondents were presented with 52 variables desorbing characteristics of retail agglomerations (see Table 2). By applying simple disciminant analyses (Malhotra, 2007) we investigated those variables which profile hedonic and 
utilitarian customer groups. By doing so we selected only those customer groups who show a more stereotypical character, i.e. $\mathrm{pH}$ and $\mathrm{pU} .^{2}$

Since we compared only two groups one function was needed to be identified in each sample which discriminate the 52 predictor variables (see Table 10). The discrimant analyses statistics showed that each function was significant $\left(x 2_{\mathrm{SST}}=190.505\right.$, $\left.\mathrm{X} 2_{\mathrm{MAL}}=254.839, \mathrm{p}<.001\right)$ in discriminating $\mathrm{pH}$ and $\mathrm{pU}$. The canonical correlations suggest that the coefficients and the groups are highly correlated. Both Wilks' Lambda $\left(\wedge_{\mathrm{SST}}=.665\right.$; $\left.\Lambda_{\mathrm{MAL}}=.601\right)$ indicate a satisfactory degree of total variance not explained by the differences among groups. In the case of the SST eight variables, while in the case of the MAL nine variables appeared to have a discriminating power between $\mathrm{pH}$ and $\mathrm{pU}$. Table 10 comprises the (standardised canonical) discriminant function coefficient of each group which evaluate the discriminating contribution of each variable. In both analyses the overall proportions of correct classification were remarkable (SST: 75.3\%; MAL: $81.3 \%$ ).

\footnotetext{
${ }^{2}$ An alternative approach would have been to consider the affiliation of a respondent to one of the four clusters as a rating point on a continuum between the extreme shopping orientations $(\mathrm{pU}$ and $\mathrm{pH})$. Multiple regression analyses for each sample could have been conducted investigating the relationship between the perception of the agglomerations' characteristics (independent variables) and the degree of hedonic versus utilitarian shopping orientation (dependent variable). As expected, the results of the interval and discrete type treatment of the problem are rather homogenous, so no additional findings would be retrieved in presenting the regression coefficients.
} 
Table 10: Results of the discriminant analyses

\begin{tabular}{|c|c|c|c|c|c|c|c|}
\hline \multicolumn{4}{|c|}{ Shopping Street (SST) } & \multicolumn{4}{|c|}{ Shopping Mall (MAL) } \\
\hline Predictor variables & $b^{*}$ & $\mathrm{pH}[\mathrm{m}(\mathrm{s})]$ & $\mathrm{pU}[\mathrm{m}(\mathrm{s})]$ & Predictor variables & $b^{*}$ & $\mathrm{pH}[\mathrm{m}(\mathrm{s})]$ & $\mathrm{pU}[\mathrm{m}(\mathrm{s})]$ \\
\hline The atmosphere is pleasant in this SST. & $.535^{\star \star *}$ & $5.4(1.4)$ & $3.9(1.5)$ & The atmosphere is pleasant in this MAL. & $.623^{\star * *}$ & $5.7(1.3)$ & $3.9(1.5)$ \\
\hline $\begin{array}{l}\text { You can get everything you can think of in this } \\
\text { SST. }\end{array}$ & $.433^{\star * *}$ & $5.6(1.3)$ & $4.1(1.7)$ & Salespeople are competent in this MAL. & $.305^{\star * \star}$ & $5.8(1.1)$ & $4.6(1.5)$ \\
\hline Stores are clearly arranged in this SST. & $.313^{* * *}$ & $5.5(1.2)$ & $4.4(1.7)$ & You can find a lot of special offers in this MAL. & $.316^{* * *}$ & $5.3(1.3)$ & $4.2(1.3)$ \\
\hline This SST is always clean. & $-.277^{* * *}$ & $4.1(1.8)$ & $4(1.7)$ & $\begin{array}{l}\text { You can find a broad range of brands in this } \\
\text { MAL. }\end{array}$ & $-.266^{\star * *}$ & $6.2(1)$ & $6(1.2)$ \\
\hline The overall price level is low in this SST. & $.227^{\star \star \star}$ & $4.2(1.3)$ & $3.5(1.3)$ & This MAL is always clean. & $-.236^{\star \star *}$ & $5.8(1.4)$ & $5.1(1.6)$ \\
\hline This SST has always enough free parking lots. & $.221^{* * *}$ & $2.2(1.5)$ & $1.8(1.4)$ & The air is pleasant in this MAL. & $.186^{\star \star \star}$ & $5.3(1.7)$ & $4.1(2.1)$ \\
\hline $\begin{array}{l}\text { The SST can be safely reached from the parking } \\
\text { lots. }\end{array}$ & $-.172^{* * *}$ & $4.5(1.7)$ & $4.6(1.9)$ & $\begin{array}{l}\text { You can get everything you can think of in this } \\
\text { MAL. }\end{array}$ & $.175^{\star * \star}$ & $6(1.3)$ & $4.8(1.8)$ \\
\hline You can find a broad range of brands in this SST. & $.166^{* * *}$ & $6.2(.9)$ & $5.6(1.2)$ & This MAL is rarely crowded. & $-.169^{* * *}$ & $2.6(1.4)$ & $2.9(1.6)$ \\
\hline \multirow{2}{*}{ This SST is rarely crowded. } & $-.158^{* * *}$ & $2.1(1.3)$ & $2.2(1.4)$ & Many relatives and friends also visit this MAL. & $.168^{\star \star \star}$ & $6.3(1.3)$ & $5.4(1.9)$ \\
\hline & & & & $\begin{array}{l}\text { Parking fees are in an acceptable range in this } \\
\text { MAL. }\end{array}$ & $-.162^{\star \star \star}$ & $6(1.5)$ & $6.3(1.7)$ \\
\hline Centroid: $\mathrm{pH}=.797 ; \mathrm{pU}=-.629$ & & & & Centroid: $\mathrm{pH}=.651 ; \mathrm{pU}=-1.017$ & & & \\
\hline Canonical correlation $=.579$ & & & & Canonical correlation= .632 & & & \\
\hline Wilks' $\wedge=.665$ & & & & Wilks' $\Lambda=.601$ & & & \\
\hline$x 2=190.505^{* * *}$ & & & & $x 2=254.839^{* * *}$ & & & \\
\hline Grouped cases correctly classified: $75.3 \%$ & & & & Grouped cases correctly classified: $81.3 \%$ & & & \\
\hline
\end{tabular}


By interpreting the standardised coefficients of the three most important variables profiling differences in both groups we see that $\mathrm{pH}$ are attracted by the atmosphere, the broad and deep assortment and clear arrangement of shops. In contrast to that $\mathrm{pU}$ appreciate that the street is clean, safe to reach from the parking lots and not crowded. Compared to the results from the MAL sample we see similarities regarding the most important variable, i.e. the atmosphere, with hedonic shoppers. The clean and rarely crowed MAL also attracts utilitarian customers in this created agglomeration. In contrast to the SST those $\mathrm{pH}$ appreciate the competency of personnel and the number of price offers in the MAL. The most discriminating variable profiling $\mathrm{pU}$ in the MAL is the broad range of well known brands.

As a consequence, hedonic shoppers in both agglomeration settings are attracted by sensory and price stimuli whereas utilitarian shoppers prefer cleanliness and the perceived low number of other customers shopping there. Nonetheless, we can only accept $\mathrm{H}_{4}$ to a certain degree since the results vary in the two samples. This again leads to the assumption that the single agglomeration effects offered by the two agglomerations are perceived differently and/or are of varying attractiveness for customers. This again suggests the impact of hedonic and utilitarian shopping orientation toward agglomeration patronage.

\section{CONCLUSION}

\section{Synopsis}

The role of hedonic and utilitarian shopping orientation has been extensively discussed in the literature (see e.g. Rintamäki et al., 2006). Nevertheless, most authors have focused their research endeavours on a product and/or on a single store level. Apart from few exceptions agglomeration issues have been neglected so far. Thus, agglomerations, no matter what kind, offer several contributions to fit with the hedonic and utilitarian shopping values for their customers. An investigation of such a psychographic orientation of agglomeration customers can therefore result in a better understanding of why customers (will) patronise certain types 
of agglomerations (Jones et al., 2006). Rising competition between created agglomerations, such as shopping centres and malls, and evolved agglomerations, such as shopping streets, have increased the importance of understanding the motivation and its consequences as to why customers shop where they shop (Rintamäki et al., 2007).

The paper provides a conceptual view towards the hedonic and utilitarian attraction of retail agglomerations. Four hypotheses are tested to investigate whether the discussed shopping value orientation of consumers show differences with regard their shopping behaviour, their perception of agglomeration characteristics and as a consequence their agglomeration patronage. Based on two extensive surveys of customers conducted in competing agglomerations the following results have been retrieved (see Table 11):

Table 11: Results of hypotheses testing

\begin{tabular}{llc}
\hline Hypothesis & Operationalisation & Acceptance \\
\hline $\mathrm{H}_{1}$ & Utilitarian customers differ significantly from hedonic customers with respect to & Yes \\
& their demographic characteristics. & No \\
$\mathrm{H}_{2}$ & $\begin{array}{l}\text { The share of hedonic customers is significantly higher in shopping streets } \\
\text { compared to shopping malls. }\end{array}$ & Yes \\
$\mathrm{H}_{3}$ & $\begin{array}{l}\text { The shopping behaviour in retail agglomerations of hedonic customers is } \\
\text { significantly different to those of utilitarian customers. }\end{array}$ \\
$\mathrm{H}_{4}$ & $\begin{array}{l}\text { Hedonic customers are attracted by different agglomeration characteristics } \\
\text { compared to utilitarian customers. }\end{array}$ & Partly \\
\hline
\end{tabular}

Both agglomerations appeal to distinctive customer groups with respect to their demographic and behavioural characterisation. The results of a cluster analysis suggest four selective shopper types based on their hedonic and/or utilitarian shopping orientation. Two of them account for (stereo) typical utilitarian and hedonic shoppers and two represent moderate forms. We found that hedonists - compared to utilitarians - can be roughly characterised as female, earn lower individual incomes and have more disposable time apart from working. All groups are relatively similar when looking at the number of household members and available cars in households.

The distribution of the shares of visits of hedonic and utilitarian customers in the two investigated agglomerations also proved to be different. We identified significantly more 
hedonists visiting the created agglomeration being studied compared to the evolved one. When investigating shopping behaviour we see differences within and between the four clusters. Hedonic shoppers make shopping trips more often, remain at the shopping destination longer but spend the same amount of money there or less. In total individual spending at each site is higher than those of utilitarians. We see that customers who appreciate pleasant atmospheric or attractive price stimuli tend to be hedonic-oriented whereas utilitarians prefer more the cleanliness of shopping sites and a moderated crowd in the evolved and created agglomerations.

The results suggest an impact of the investigated value orientation of agglomerations' customers on their shopping behaviour and their agglomeration patronage. Furthermore, we notice a specific characterisation of customers, not only from a demographic but also from a psychographic point of view. This leads to the conclusion that agglomerations of a distinct kind applying a different kind of marketing mix tend to attract (shopping) hedonists and utilitarians to a varying degree.

\section{Limitations and Outlook for Further Research}

There are some limitations in our research that may inspire future work in this area which can be summarised as follows:

Selected agglomeration: We investigate supra-regional agglomerations which can be found in every capital city in the western retailing world. However, the number of agglomerations appealing to regional customers is comparably high and are, therefore, of similar importance for retail research and management. Compared to large super-regional agglomerations, smaller ones, i.e. loose retail clusters in town centres, shopping streets and centres, contain a distinctive tenant mix, which do not include as many stores belonging to global acting retail enterprises but do include more independent small and medium-sized retail stores. Thus, those agglomerations satisfy a more regional demand and offer goods and services at a 
more regional taste. The results at hand should therefore be interpreted according to this supra-regional and international character of the investigated retail sites.

Furthermore is has to be noted that evolved and created retail agglomeration formats are represented by a shopping street and a shopping mal in our empirical study. As a further limitation it should be noted that agglomeration types, such as inner city retail clusters or factory outlet centres, lifestyle centres etc., have been neglected. As a consequence, further research could take into account various other types of agglomerations of each format since they may appeal to hedonic and utilitarian shopper types in a different way (Reynolds et al., 2002).

Sample (selection procedure): Although applying a random sampling procedure the external validity of our empirical results is limited to these customers having shopped at that period of time. Additionally, the respondents were confronted with questions regarding the agglomeration targeted at the time of the interview. An evaluation in another period of time of the year would result in a different selection of respondents having different shopping tasks and may respond to our question in a different way.

Scope of analyses: The two clientele were treated as homogenous groups in our analyses. No distinction was made - apart from shopping orientation issues - according to demographic or behavioural variables. It could be interesting to focus, e.g., on gender specific differences in further analyses or follow up studies (Campbell, 1997).

Focused shopping values: Concerning the discussion and evaluation of shopping values and shopper types, we based our argumentation and measurement on the multi-item scale of Babin et al. (1994). We therefore did not explicitly include, besides others, the social or entertainment values of shopping (Arnold and Reynolds, 2003; Reynolds et al., 2002). Further research should therefore provide a more extended view towards shopping orientation or attitudes. 
General shopping orientation: We evaluated the shopping orientation of each respondent in general and have therefore neglected the fact that this can vary along with the shopping situation and shopping task (Zhuang et al., 2006; Holbrook and Hirschman, 1982). It may be especially interesting to investigate the impact of the type of product or service sought on the shopping orientation and/or on agglomeration patronage issues.

Focus on identifying differences: By identifying significant differences between groups with respect to demographic, behavioural but also perceptual variables we can only conclude that the shopping orientation does have an impact on patronage issues. This does not include evidence towards the strength of this moderating effect. By applying the structural equation modelling approach or other regression type analysis the impact of the proposed latent construct of hedonic and utilitarian on the perception of agglomeration's characteristics as well as the evaluation of agglomeration's attractiveness could be investigated in more detail. 


\section{LITERATURE}

Alzubaidi, H., Vignali, C. and Davies, B. J. and Schmidt, R. A. (1997) 'Town centre versus out-of-town shopping: a consumer perspective', International Journal of Retail \& Distribution Management, 25(2), pp. 78-89.

Arentze, T. A. and Timmermans, H. J. P. (2001) 'Deriving performance indicators from models of multipurpose shopping behavior', Journal of Retailing and Consumer Services, 8(6), pp. 325-334.

Arnold, M. J. and Reynolds, K. E. (2003) 'Hedonic shopping motivations', Journal of Retailing, 79(2), pp. 77-95.

Babin, B. J., Darden, W. R. and Griffin, M. (1994) 'Work and/or fun: Measuring hedonic and utilitarian shopping value', Journal of Consumer Research, 20(4), pp. 644-656.

Bacon, R. W. (1995) 'Combined trips and the frequency of shopping', Journal of Retailing and Consumer Services, 2(3), pp. 175-183.

Baker, R. G. V. (2006) Dynamic trip modelling. From shopping centres to the Internet, (Dordrecht: Springer).

Baker, R. G. V. (2002) 'The impact of the deregulation of retail hours on shopping trip patterns in a mall hierarchy: an application of the RASTT model to the Sydney Project (19801998) and the global vacant shop problem', Journal of Retailing and Consumer Services, 9(3), pp. 155-171.

Batra, R. and Ahtola, O. T. (1991) 'Measuring the hedonic and utilitarian sources of consumer attitudes', Marketing Letters, 2(2), pp. 159-170.

Bearden, W. O. (1977) 'Determinant attributes of store patronage - Downtown versus outlying shopping centers', Journal of Retailing, 53(2), pp. 15-22.

Berman, B. and Evans, J. R., (2007) Retail management. A strategic approach, (Upper Saddle River/NJ: Pearson Prentice Hall).

Bell, D. R., Ho, T.-H. and Tang, C. S. (1998) 'Determining where to shop: Fixed and variable costs of shopping', Journal of Marketing Research, 35(3), pp. 352-369.

Bellenger, D. N., Robertson, D. H. and Greenberg, B. A. (1977) 'Shopping center patronage motives', Journal of Retailing, 53(2), pp. 29-38.

Bezdek, J.C. (1981) Pattern recognition with fuzzy objective function algorithms, (Norwell: Kluwer Academic Publishers).

Bhatnagar, A. and Ratchford, B. T. (2003) 'A model of retail format competition for nondurable goods', International Journal of Research in Marketing, 21(1), pp. 39-59.

Bloch, P. H., Ridgway, N. M. and Dawson, S. A. (1994) 'The shopping mall as consumer habitat', Journal of Retailing, 70(1), pp. 23-42.

Boots, B. and South, R. (1997) 'Modeling retail trade areas using higher-order, multiplicatively weighted Voronoi diagrams', Journal of Retailing, 73(4), pp. 519-536. 
Bubuska, R., Van der Veen, P.J. and Kaymak, U. (2002) 'Improved covariance estimation for Gustafson-Kessel clustering', Proceedings of the IEEE International Conference on Fuzzy Systems, (Honolulu/Hawaii), pp. 1081-1085.

Campbell, C. (1997). Shopping, Pleasure and the sex war. In The Shopping Experience, ed. P. Falk and C. Campbell, pp. 166-176, (London: Sage).

Campbell, D. T. (1955) 'The informant in quantitative research', American Journal of Sociology, 60(4), pp. 339-342.

Dellaert, B. G. C., Arentze, T. A., Bierlaire, M., Borgers, A. W. J. T. and Harry J. P. (1998) 'Investigating consumers', tendency to combine multiple shopping purposes and destinations', Journal of Marketing Research, 35(2), pp. 177-188.

Dennis, C. (2005) Objects of Desire. Consumer behaviour in shopping centre choices, (Houndmills: Palgrave Macmillan).

Dimitriadou, E., Dolnicar, S. and Weingessel, A. (2002): 'An examination of indexes for determining the number of clusters in binary data sets', Psychometrika, 67(1), pp. 137-160.

Finn, A. and Louviere, J. J., (1996) 'Shopping center image, consideration, and choice: anchor store contribution', Journal of Business Research, 35(3), pp. 241-251.

Ghosh, A. (1986) 'The Value of a Mall and Other Insights from a Revised Central Place Model', Journal of Retailing, 62(1), pp. 79-97.

Granzin, K. L. and Bahn, K. D. (1989) 'Consumer logistics: Conceptualization, pertinent issues and a proposed program for research', Academy of Marketing Science, 17(1), pp. 91101.

Granzin, K. L., Painter, J. J. and Bahn, K. D. (2005) 'An empirical test of household's participation in the distribution supply chain process', Journal of Marketing Channels, 14 (4), pp. 67-89.

Granzin, K.L., Painter, J.J. and Valentin, E.K. (1997) 'Consumer Logistics as a basis for segmenting retail markets. An exploratory inquiry', Journal of Retailing and Consumer Services, 4 (2), pp. 99-107.

Gustafson, D.E. and Kessel, W.C. (1979) 'Fuzzy clustering with fuzzy covariance matrix', Proceedings of the IEEE CDC, (San Diego/California), pp. 761-766.

Haytko, D. L. and Baker, J. (2004) 'It's all at the mall: exploring adolescent girls' experiences', Journal of Retailing, 80(1), pp. 67-83.

Hirschman, E. C. and Holbrook, M. B. (1982) 'Hedonic consumption: Emerging concepts, methods and propositions', Journal of Marketing, 46(3), pp. 92-110.

Holbrook, M. B. and Hirschman, E. C., (1982) 'The experiential aspects of consumption: Consumer fantasies, feelings, and fun', Journal of Consumer Research, 9(2), pp. 132-140.

ICSC (International Counsil of Shopping Centers) (2002) 'The development of shopping centres in Europe 2002," www.icsc.org/international/EuropeReviewFINAL.pdf.

ICSC (International Counsil of Shopping Centers) (2005) 'The development of shopping centres - Scope US 2005," http://www.icsc.org/srch/rsrch/scope/current/index.php. 
Ingene, C. A. (1984) 'Productivity and functional shifting in spatial retailing: Private and social perspectives', Journal of Retailing and Consumer Services, 60(3), pp. 15-26.

Jin, B. and Sternquist, B. (2004) 'Shopping is truly a joy', The Service Industries Journal, 24(6), pp. 1-18.

Jones, M. A., Reynolds, K. E. and Arnold, M. J., (2006) 'Hedonic and utilitarian shopping value: Investigating differential effects on retail outcomes', Journal of Business Research, 59(9), pp. 974-981.

Kang, J. and Kim, Y.-K. (1999) 'Role of entertainment in cross-shopping and in the revitalization of regional shopping centers', Journal of Shopping Center Research, 6(2), pp. 41-71.

Kaufman, L. and Rousseeuw, P.J. (2005) Finding groups in data: An introduction to cluster analysis, (Hoboken/NJ: Wiley-Interscience).

Kim, H.-S. (2006) 'Using hedonic and utilitarian shopping motivations to profile inner city consumers', Journal of Shopping Center Research, 13(1), pp. 57-79.

Kim, Y.-K. (2002) 'Consumer value: An application to mall and Internet shopping', International Journal of Retail \& Distribution Management, 30(11/12), pp. 595-602.

Langrehr, F. W. (1991) 'Retail shopping mall semiotics and hedonic consumption', Advances in Consumer Research, 18(1), pp. 428-433.

Malhotra, N. K. (2007) Marketing research. An applied orientation, (Upper Saddle River/NJ: Pearson Prentice Hall).

Marjanen, H. (1995) 'Longitudinal study on consumer spatial shopping behaviour with special reference to out-of-town shopping. Experiences from Turku, Finland', Journal of Retailing and Consumer Services, 2(3), pp. 163-174.

Mazanec, J. A. and Strasser, H. (2000) A nonparametric approach to perceptions-based market segmentation: Foundations, (Vienna: Springer).

Oppewal, H. and Holyoake, B. (2004) 'Bundling and retail agglomeration effects on shopping behavior', Journal of Retailing and Consumer Services, 11(2), pp. 61-74.

Prendergast, G., Marr, N. and Jarratt, B. (1998) 'Retailers' views of shopping centres: a comparison of tenants and non-tenants', International Journal of Retail \& Distribution Management, 26(4), pp. 162-171.

Reynolds, K. E., Ganesh, J. and Luckett, M. (2002) 'Traditional malls vs. factory outlets: comparing shopper typologies and implications for retail strategy', Journal of Business Research, 55(9), pp. 687-696.

Reinartz, W. J. and Kumar, V. (1999) 'Store-, market-, and consumer-characteristics: The drivers of store performance', Marketing Letters, 10(1), pp. 5-23.

Rintamäki, T., Kanto, A., Kuusela, H. and Spence, M. T. (2006) 'Decomposing the value of department store shopping into utilitarian, hedonic and social dimensions', International Journal of Retail \& Distribution Management, 34(1), pp. 6-24.

Rintamäki, T., Kuusela, H. and Mitronen, L. (2007) 'Identifying competitive customer value propositions in retailing', Managing Service Quality Journal, forthcoming. 
Ruiz, J. P., Chebat, J.-C. and Hansen, P. (2003) 'Another trip to the mall: a segmentation study of customers based on their activities', Journal of Retailing and Consumer Services, 11(1), pp. 1-18.

Severin, V., Louviere, J. J. and Finn, A. (2001) 'The stability of retail shopping choices over time and across countries', Journal of Retailing, 77(2), pp. 185-202.

Sheth, J. N., Newman, B. I. and Gross, B. (1991) 'Why we buy what we buy: a theory of consumption values', Journal of Business Research, 22(2), pp. 159-170.

Sheth, J. N., Mittal, B. and Newman, B. I. (1999) Customer behavior. Consumer behavior and beyond, (Fort Worth: Dryden Press).

Statistik Austria (2007) Statistisches Jahrbuch Österreichs 2006 [statistical yearbook of Austria 2006), (Vienna: Verlag Österreich).

Sudman, S. (1980) 'Improving the quality of shopping center sampling', Journal of Marketing Research, 17(4), pp. 423-431.

Swinyard, W. R. (1998) 'Shopping mall customer values: the national mall shopper and the list of values', Journal of Retailing and Consumer Services, 5(3), pp. 167-172.

Teller, C. and Reutterer, T. (2007) 'The evolving concept of retail attractiveness: What makes retail agglomerations attractive when customer shop at them?' Journal of Retailing and Consumer Services, forthcoming.

Van Kenhove, P., De Wulf, K. and Van Waterschoot, W. (1999) 'The impact of task definition on store-attribute saliences and store choice', Journal of Retailing, 75(1), pp. 125-137.

Wakefield, K. L. and Baker, J. (1998) 'Excitement at the mall: Determinants and effects on shopping response', Journal of Retailing, 74(4), pp. 515-539.

Westbrook, R. A. and Black, W. C. (1985) 'A motivation-based shopper typology', Journal of Retailing, 61(1), pp. 78-103.

Woodside, A. G. and Trappey, R. J. (1992) 'Finding out why customers shop your store and buy your brand: Automatic cognitive processing models of primary choice', Journal of Advertising Research, 32(6), pp. 59-78.

Zhuang, G., Tsang, A. S. L., Zhou, N., Li, F. and Nicholls, J. A. F. (2006) 'Impacts of situational factors on buying decisions in shopping malls: An empirical study with multinational data', European Journal of Marketing, 40(1/2), pp. 17-43. 


\section{APPENDIX}

Table 12: Applied multi-item scale

\begin{tabular}{|c|c|c|c|c|c|c|c|c|c|c|c|}
\hline \multirow[b]{2}{*}{ Factor } & \multirow[b]{2}{*}{$\#$} & \multirow[b]{2}{*}{ Item } & \multirow[b]{2}{*}{$\begin{array}{l}\mathrm{m} \\
(\mathrm{s})\end{array}$} & \multirow[b]{2}{*}{$\alpha$} & \multicolumn{7}{|c|}{ Differences between groups } \\
\hline & & & & & $\begin{array}{l}\stackrel{\supset}{\imath} \\
\text { I }\end{array}$ & $\begin{array}{l}\frac{T}{w} \\
\hat{1} \\
\frac{1}{2}\end{array}$ & $\begin{array}{l}2 \\
\infty \\
\uparrow \\
\frac{1}{\infty}\end{array}$ & 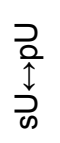 & 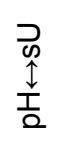 & $\begin{array}{l}\frac{\partial}{a} \\
\frac{1}{1} \\
\frac{1}{\infty}\end{array}$ & $\begin{array}{l}\frac{2}{2} \\
\frac{1}{1} \\
\frac{1}{2}\end{array}$ \\
\hline \multirow{13}{*}{$\begin{array}{l}\text { Hedonic } \\
\text { shopping } \\
\text { value }\end{array}$} & h1 & Shopping really means joy to me. & $\begin{array}{c}5.2 \\
(1.7)\end{array}$ & & *** & * & *** & $* * *$ & $* * *$ & $* * *$ & $* * *$ \\
\hline & h2 & $\begin{array}{l}\text { Sometimes I continue to shop, } \\
\text { not because I have, but I want to. }\end{array}$ & $\begin{array}{c}4.6 \\
(1,8)\end{array}$ & & *** & * & *** & $* * *$ & $* * *$ & $* * *$ & *** \\
\hline & h3 & $\begin{array}{l}\text { A shopping trip really feels like } \\
\text { an escape. }\end{array}$ & $\begin{array}{c}4.3 \\
(2.1)\end{array}$ & & $* * *$ & $* * *$ & *** & $* * *$ & $* * *$ & $* * *$ & *** \\
\hline & h4 & $\begin{array}{l}\text { Compared to other things I could } \\
\text { do, shopping is really enjoyable. }\end{array}$ & $\begin{array}{c}4.4 \\
(1.9)\end{array}$ & & $* * *$ & $* * *$ & $* * *$ & $* * *$ & $* * *$ & $* * *$ & *** \\
\hline & h5 & $\begin{array}{l}\text { I enjoy being immersed in } \\
\text { exciting new products. }\end{array}$ & $\begin{array}{c}4.6 \\
(1.9)\end{array}$ & & $* * *$ & $* * *$ & $* * *$ & $* * *$ & $* * *$ & $* * *$ & $* * *$ \\
\hline & h6 & $\begin{array}{l}\text { I enjoy shopping for its own sake, } \\
\text { not just for the items I may } \\
\text { purchase. }\end{array}$ & $\begin{array}{c}4.4 \\
(1.9)\end{array}$ & & $* * *$ & *** & *** & $* * *$ & $* * *$ & $* * *$ & *** \\
\hline & h7 & $\begin{array}{l}\text { I have a good time because I am } \\
\text { able to act on the 'spur of the } \\
\text { moment'. }\end{array}$ & $\begin{array}{c}4.6 \\
(1.9)\end{array}$ & .938 & $* * *$ & $* * *$ & $\star * *$ & $* * *$ & $* * *$ & $\star * *$ & $* * *$ \\
\hline & h8 & $\begin{array}{l}\text { During the trip, I feel the } \\
\text { excitement of the hunt. }\end{array}$ & $\begin{array}{c}3.2 \\
(2.0)\end{array}$ & & $* * *$ & $\star \star \star *$ & - & $* * *$ & $* * *$ & $* * *$ & $\star * *$ \\
\hline & h9 & $\begin{array}{l}\text { While shopping, I am able to } \\
\text { forget my problems. }\end{array}$ & $\begin{array}{l}3.3 \\
(2)\end{array}$ & & $* * *$ & $* * *$ & 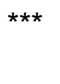 & $* * *$ & $* * *$ & $* * *$ & $* * *$ \\
\hline & h10 & $\begin{array}{l}\text { While shopping, I feel a sense of } \\
\text { adventure. }\end{array}$ & $\begin{array}{c}3.4 \\
(1.9)\end{array}$ & & $* * *$ & $\star * *$ & $\star * \star$ & $* * *$ & $* * *$ & $* * *$ & $* * *$ \\
\hline & h11 & $\begin{array}{l}\text { A shopping trip is not a very nice } \\
\text { time out.* }\end{array}$ & $\begin{array}{l}4.4 \\
(2)\end{array}$ & & $* * *$ & $* * *$ & $* * *$ & $* * *$ & $* * *$ & $* * *$ & $* * *$ \\
\hline & h12 & $\begin{array}{l}\text { I feel really unlucky during a } \\
\text { shopping trip.* }\end{array}$ & $\begin{array}{c}4.1 \\
(1.9)\end{array}$ & & $* * *$ & *** & $* * *$ & $* * *$ & $* * *$ & $* * *$ & $* * *$ \\
\hline & h13 & $\begin{array}{l}\text { I am able to do a lot of } \\
\text { fantasizing during a shopping } \\
\text { trip. }\end{array}$ & $\begin{array}{c}4.7 \\
(1.8)\end{array}$ & & $* * *$ & $* * *$ & $* * *$ & $* * *$ & $* * *$ & $* * *$ & $* * *$ \\
\hline \multirow{6}{*}{$\begin{array}{l}\text { Utilitarian } \\
\text { shopping } \\
\text { value }\end{array}$} & $\mathrm{u} 1$ & $\begin{array}{l}\text { I accomplish just what I want on } \\
\text { shopping trip. }\end{array}$ & $\begin{array}{c}3.8 \\
(2.1)\end{array}$ & & $\star * * *$ & $\star \star \star *$ & 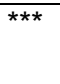 & $* * *$ & * & $\star \star * *$ & 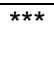 \\
\hline & u2 & $\begin{array}{l}\text { While shopping, I just find what I } \\
\text { am looking for.* }\end{array}$ & $\begin{array}{c}3.7 \\
(1.9)\end{array}$ & & - & $\star * *$ & $* * *$ & $* *$ & $* * *$ & $* * *$ & $* * *$ \\
\hline & u3 & $\begin{array}{l}\text { I am disappointing when I have } \\
\text { to go to another store to } \\
\text { complete my shopping }\end{array}$ & $\begin{array}{c}4.4 \\
(2.1)\end{array}$ & .62 & $* * *$ & $\star * *$ & $\star \star \star *$ & $* *$ & - & $* * *$ & $* * *$ \\
\hline & $\mathrm{u} 4$ & $\begin{array}{l}\text { I am delighted if the shopping trip } \\
\text { is over quickly. }\end{array}$ & $\begin{array}{c}5 \\
(1.9)\end{array}$ & & $* * *$ & $* * *$ & $\star \star * *$ & $* * *$ & $* * *$ & $* * *$ & $* * *$ \\
\hline & u5 & $\begin{array}{l}\text { A shopping trip is rather } \\
\text { successful.* }\end{array}$ & $\begin{array}{c}2.8 \\
(1.7)\end{array}$ & & $* * *$ & *** & $\star \star \star *$ & - & * & $* * *$ & - \\
\hline & u6 & $\begin{array}{l}\text { Mostly, I cannot buy what I really } \\
\text { want. }\end{array}$ & $\begin{array}{c}3.2 \\
(1.9)\end{array}$ & & $* * *$ & *** & *** & $* * *$ & $* * *$ & $* * *$ & $* * *$ \\
\hline \multicolumn{12}{|c|}{ 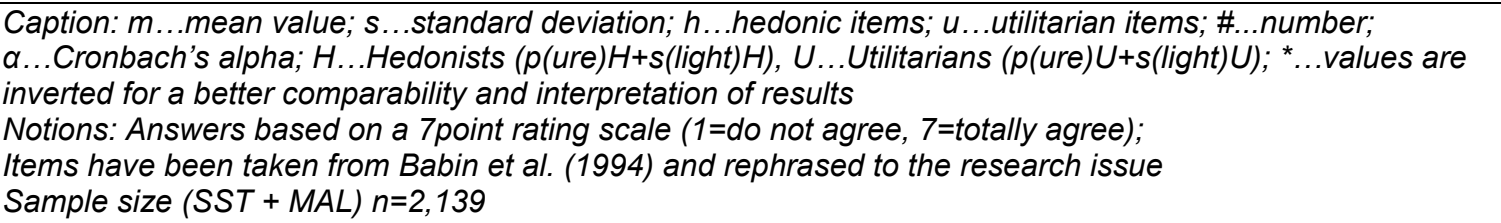 } \\
\hline
\end{tabular}

